\title{
The Content Analysis of Bisphenol A (BPA) on Water in Plastic Glass with Varying Temperatures and Contact Times using UV-VIS Spectrophotometer
}

\author{
Bayu Nugroho ${ }^{1}$, Yudhiakto Pramudya ${ }^{2}$, Widodo ${ }^{2}$ \\ ${ }^{1}$ Politeknik Ilmu Pelayaran Balikpapan \\ Jalan Kesatrian KM.08 Soekarno Hatta, Karang Joang, Balikpapan 76127 \\ bayun4030@gmail.com \\ ${ }^{2}$ Universitas Ahmad Dahlan \\ Jalan Pramuka no 42, Yogyakarta, Daerah Istimewa Yogyakarta \\ yudhiakto.pramudya@pfis.uad.ac.id
}

\begin{abstract}
This study aims to analyze the content of Bisphenol A (BPA) on various temperature and contact times between the plastic bag and water. For analysis of BPA, a sample made with variations of temperature $\left( \pm 70^{\circ} \mathrm{C}, \pm 80^{\circ} \mathrm{C}, \pm 90^{\circ} \mathrm{C}\right)$ and contact time $(5$ minutes, 10 minutes, 15 minutes) using nine samples. To determine the concentration of BPA, Lambert-Beer law was employed. According to the analysis of data, the content of BPA on the temperature variation showed that the higher the temperature of the sample, the higher the content of Bisphenol A in the sample. The content of BPA with a variation of contact times stated that with the longer contact time, the higher the content of BPA.
\end{abstract}

Keywords :Bisphenol A (BPA),UV-VIS Spectrophotometer, Temperatures, Contact Times

\section{Introduction}

Plastic materials has greatly expanded.There are are packaging materials, food containers and plastic cups. Bisphenol A (BPA) is a chemical compound found in polycarbonate plastic (PC) which is a dangerous additive. BPA has the molecular formula of $\mathrm{C} 15 \mathrm{H} 16 \mathrm{O} 2$, built by two phenol rings connected by a methyl bridge containing two methyl functional groups. If BPA is subjected to high temperatures, the molecular bond can be easily released.

The imperfect polymerization ofplastic material that occurs during production or depolymerization due to intentional heating for sterilization or unintentional purposes during storage can release BPA and its derivatives to food by 4-23 $\mu \mathrm{g} /$ pack, drinks by 7 - $58 \mu \mathrm{g} / \mathrm{g}$, and saliva by $90-913$ $\mu \mathrm{g} / \mathrm{saliva}$ which was collected for one hour after installation of dental sealants [1][2][3]..

In 2007, EFSA has determined an acceptable daily BPA intake (Tolerable Daily Intake, TDI) of
$50 \mu \mathrm{g} / \mathrm{kg} /$ day or $\mathrm{ppb} /$ day so that the use of BPA remains declared safe. The effects of BPA for body can cause breast cancer, prostate cancer, kidney disorders, damage to eggs and chromosomes, interfere with the quality of the hormone testosterone, interfere with sperm production, hyperactivity, obesity due to increased fat cell production, insulin resistance, and liver disorders. The plastic cups are often used as a container for drinking coffee or tea in hot conditions for a long time. Hence, it is possible that the migration of BPA from plastic material into coffee or tea is occurred. BPA migration to food needs serious attention because of the dangers to health such as causing: brain development disorders, breast cancer, prostate cancer, kidney disorders, reproductive disorders, and decreased sperm quality.

Due to the danger of BPA migration, number of methods have been developed to analyze BPA content, one of which is the UV-VIS Spectrophotometer. The method is based on the absorbance of electromagnetic wave radiation by 
The Content Analysis of Bisphenol a (Bpa) on Water in Plastic Glass with...

materials for wavelengths of UV light to visible light. Using a UV-VIS Spectrophotometer it is possible to accurately detect the content of Bisphenol A (BPA) in solution.The UV-VIS spectrophotometer is a tool for quantitatively and qualitatively low-level analysis of elements based on the peaks produced in a particular element spectrum at 200-400 nm UV wavelength and in visible light regions (visible, 400-750 nm). The spectroscopy method has been employed on aluminium concentration in beverages [4] and limonene concentration in kayu putih oil measurement [5]. The method was also applied succesfully on BPA content analysis on water as function of contact time between hot water and plastic glass [6]

The principle of Spectrophotometer UV-VIS is when a light source or radiation source with a certain wavelength is passed on a substance, then a certain amount of light will be absorbed by the substance. Absorption of light by substances is influenced by the energy level of the substance, where each compound has a certain energy level related to the type of possible movement of a molecule such as translational motion, rotational motion, and vibration motion as shown in Figure 1.

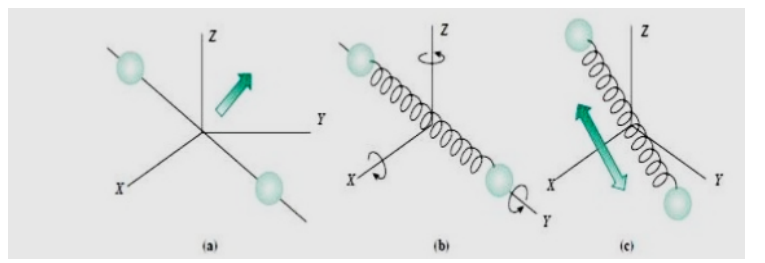

Figure 1. Possible movements of diatomic molecules. (a) Translational motion (b) rotational motion (c) vibration motion [7].

\section{Method of Research}

A. Tools and materials

Tools and materials in this research are: Computer, Shimadzu UV-1800 UV-VIS Spectrophotometer, Laptop, Mini Lab Quest, Logger Pro Software, Temperature Sensor, Ultrasonicator, Digital Heater, Digital Balance, Pumpkin Measure, Glass Funnel, Glassware, Mineral Water (3 liters), Crystal $\mathrm{NaOH}$ (4 grams), Plastic drink glasses (9 pieces), Cardboard Boxes (size: $31 \mathrm{~cm} \mathrm{x} 13 \mathrm{~cm} \mathrm{x} 14$ $\mathrm{cm})$.

\section{B. Research procedure}

The UV-VIS Spectrophotometer is connected to a computer to operate the Shimadzu UV-1800 UV-VIS Spectrophotometer directly using the UV Probe Software. The 4 grams of $\mathrm{NaOH}$ crystals is prepared by inserting $\mathrm{NaOH}$ crystals into a $50 \mathrm{~mL}$ beker glass. The $\mathrm{NaOH}$ crystals were mixed by 20 $\mathrm{mL}$ of mineral water. The solution were placed in the ultrasonicator to dissolve $\mathrm{NaOH}$ crystals.

The $1 \mathrm{~N}$ of $\mathrm{NaOH}$ solution is made on a temperature of $400^{\circ} \mathrm{C}$ : The $20 \mathrm{~mL} \mathrm{NaOH}$ solution was put into a $100 \mathrm{~mL}$ volumetric flask then added $80 \mathrm{~mL}$ of mineral water using a glass funnel until the boundary markings. Then, it was put into a 100 $\mathrm{mL}$ beaker and heated with a digital heater until a $400^{\circ} \mathrm{C}$ temperature. The solution temperature was measured using a temperature sensor that was connected to the Mini Quest Lab and laptop and analyzed with Logger Pro software.

The sample solutions are prepared according to table1.

Table 1. Variation in samples

\begin{tabular}{|c|c|c|c|}
\hline \multirow{2}{*}{$\begin{array}{c}\text { Contact } \\
\text { Times } \\
\text { (minute) }\end{array}$} & \multicolumn{3}{|c|}{ Temperatures $\left({ }^{\circ} \mathrm{C}\right)$} \\
\hline & \pm 70 & \pm 80 & \pm 90 \\
\hline \multirow[t]{2}{*}{5} & Sample & Sample & Sample \\
\hline & A & $\mathrm{D}$ & G \\
\hline \multirow[t]{2}{*}{10} & Sample & Sample & Sample \\
\hline & B & E & $\mathrm{H}$ \\
\hline \multirow[t]{2}{*}{15} & Sample & Sample & Sample \\
\hline & $\mathrm{C}$ & $\mathrm{F}$ & I \\
\hline
\end{tabular}

Here, the condition for each temperature group of samples :

a. Samples on temperature of $\pm 70^{\circ} \mathrm{C}$ : In each sample, put $110 \mathrm{ml}$ of mineral water into a 200 $\mathrm{mL}$ beaker and then heated with a digital heater to a temperature of $\pm 70^{\circ} \mathrm{C}$ as measured by a temperature sensor. After that $\pm 70^{\circ} \mathrm{C}$ of mineral water was put into A plastic cup for 5 minutes, B plastic cups for 10 minutes, and $\mathrm{C}$ plastic cups for 15 minutes, after which each sample was put in a cardboard box to maintain the temperature. 
The water from each sample was taken $90 \mathrm{~mL}$ and put into a $100 \mathrm{ml}$ measuring cup and mixed with $10 \mathrm{~mL}$ of $1 \mathrm{~N}$ of $\mathrm{NaOH}$ solution with a temperature of $40^{\circ} \mathrm{C}$, so that a $\mathrm{NaOH}$ solution with a concentration of $10 \%$ was obtained.

b. Samples on temperature of $\pm 80^{\circ} \mathrm{C}$ : In each sample, put $110 \mathrm{ml}$ of mineral water into a 200 $\mathrm{mL}$ beaker and then heated with a digital heater to a temperature of $\pm 80^{\circ} \mathrm{C}$ as measured by a temperature sensor. After that the mineral water of $\pm 80^{\circ} \mathrm{C}$ was put in a plastic cup $\mathrm{D}$ for 5 minutes, plastic cup $\mathrm{E}$ for 10 minutes, and a plastic cup $F$ for 15 minutes, after which each sample was put in a cardboard box to maintain the temperature. The water from each sample was taken $90 \mathrm{~mL}$ and put into a $100 \mathrm{ml}$ measuring cup and mixed with $10 \mathrm{~mL}$ of $1 \mathrm{~N}$ of $\mathrm{NaOH}$ solution with a temperature of $40^{\circ} \mathrm{C}$, so that a $\mathrm{NaOH}$ solution with a concentration of $10 \%$ was obtained.

c. Samples on temperature $\pm 90^{\circ} \mathrm{C}$ : In each sample, put $110 \mathrm{ml}$ of mineral water into a $200 \mathrm{~mL}$ beaker and then heated with a digital heater to a temperature of $\pm 90^{\circ \circ} \mathrm{C}$ as measured by a temperature sensor. After that $\pm 90^{\circ} \mathrm{C}$ of mineral water is put into a plastic $\mathrm{G}$ glass for 5 minutes, $\mathrm{H}$ plastic cups for 10 minutes, and plastic cups I for 15 minutes, after which each sample is put in a cardboard box to maintain the temperature. The water from each sample was taken $90 \mathrm{~mL}$ and put into a $100 \mathrm{ml}$ measuring cup and mixed with $10 \mathrm{~mL}$ of $1 \mathrm{~N} \mathrm{NaOH}$ solution with a temperature of $40^{\circ} \mathrm{C}$, so that a $\mathrm{NaOH}$ solution with a concentration of $10 \%$ was obtained.

C. Analysis Method

The standard Bisphenol A (BPA) absorption spectrum using UV-VIS Spectrophotometer can be seen as shown in Figure 2. The Figure is presented in the supplementary material.

As shown in Figure 2, the absorption area of Bisphenol A (BPA) compounds is at a wavelength of $200 \mathrm{~nm}-300 \mathrm{~nm}$ with maximum absorbance at a wavelength of $\pm 214 \mathrm{~nm}$.

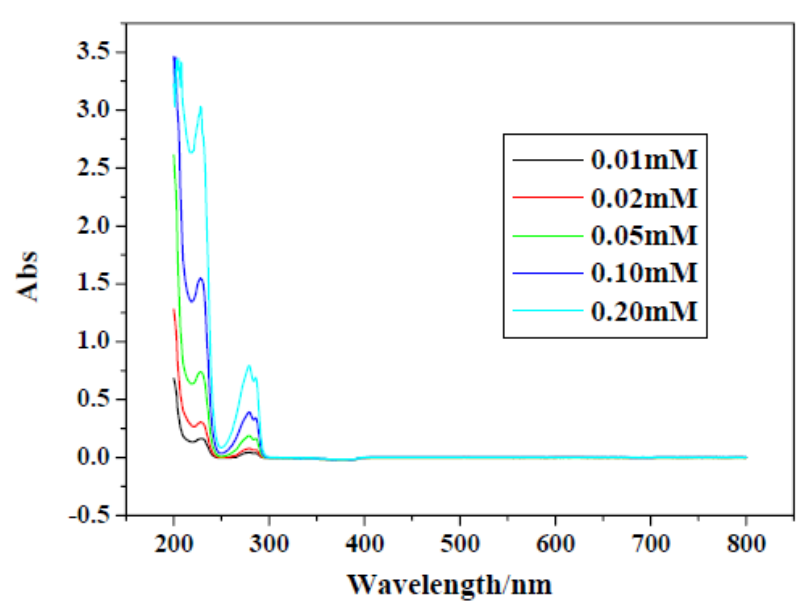

Figure 2. Bisphenol A (BPA) absorption spectrum [8].

The Lambert-Beer Law defines the relationship between the sample concentration and the number of sources of radiation (energy) absorbed by the sample as in equation (1) :

$$
A=\varepsilon d C
$$

with:

$$
\begin{aligned}
& A=\text { Absorbance } \\
& \varepsilon=\text { Constant Absorptivity Molar }\left(\mathrm{L} \cdot \mathrm{mM}^{-1} \cdot \mathrm{cm}^{-1}\right) \\
& d=\text { thickness of cuvette }(\mathrm{cm}) \\
& C=\text { Concentration of Samples }\left(\mathrm{mM} \cdot \mathrm{L}^{-1}\right)
\end{aligned}
$$

From the figure 2 and using the Tracker, the constant Absorptivity Molar can be determined using Tracker software.

\section{Results And Discussion}

\section{A. Spektrum Bisphenol A (BPA)}

BPA absorption spectrum in each sample was obtained in the form of overlay graphs of temperature and contact time relationships as shown in Figure 3.

Based on the spectrum indicated by the overlay 3 spectrum graph for variations in temperature and contact time, the maximum absorbance is entirely at a wavelength of $\pm 214 \mathrm{~nm}$. The peak wavelength is confirmed by the standard spectrum of Bisphenol A (BPA) as shown in Figure 2. 
The Content Analysis of Bisphenol a (Bpa) on Water in Plastic Glass with...

Table 2. Maximum absorbance of each sample

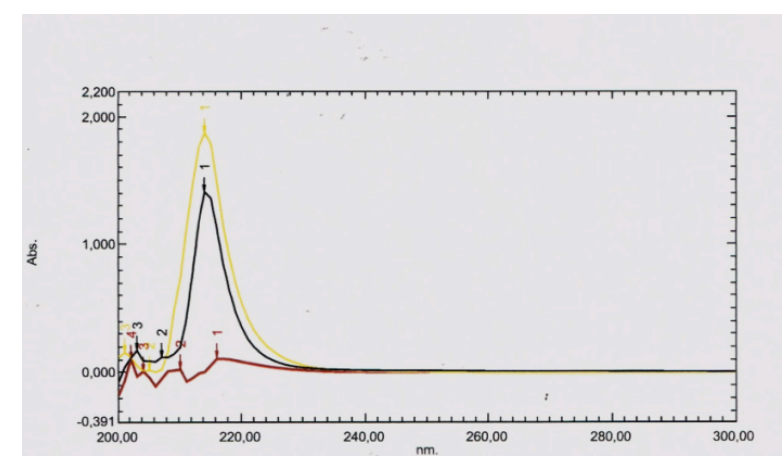

(a)

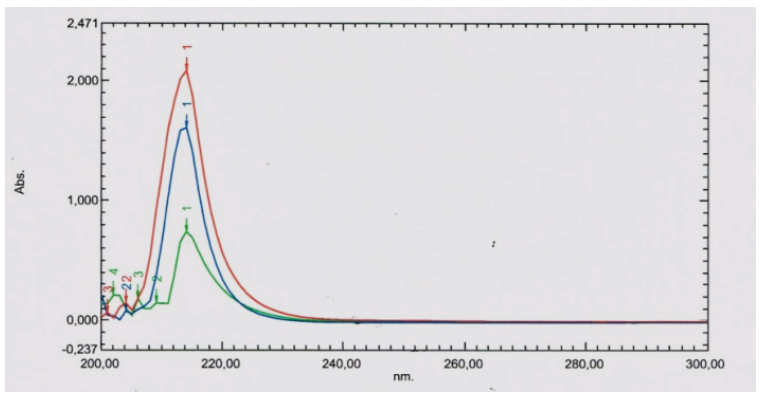

(b)

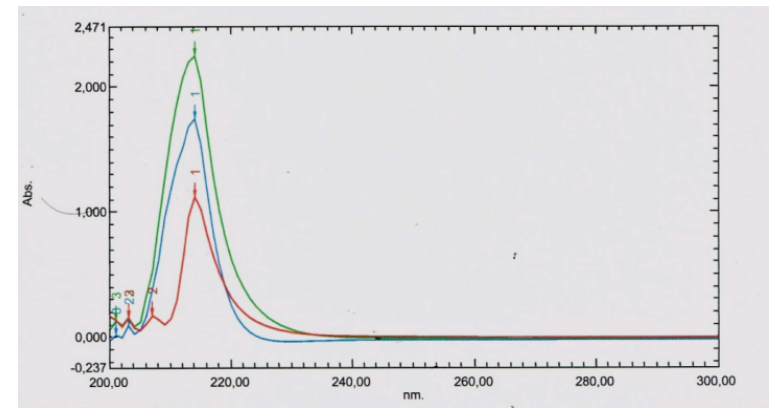

(c)

Figure 3. Sample overlay graph at (a) 5 minutes (b) 10 minutes (c) 15 minutes contact time

B. Bisphenol A (BPA) content with temperature variations

In the analysis of Bisphenol A (BPA) content with a temperature variation of $\pm 70^{\circ} \mathrm{C}$ to $\pm 90^{\circ} \mathrm{C}$ using a UV-VIS Spectrophotometer, the maximum absorbance values in each sample were obtained as shown in table 2.

\begin{tabular}{|c|c|c|c|}
\hline \multirow{2}{*}{$\begin{array}{c}\text { Contact } \\
\text { Times } \\
\text { (Minute) }\end{array}$} & \multicolumn{3}{|c|}{ Temperatures $\left({ }^{\circ} \mathrm{C}\right)$} \\
\hline & $\begin{array}{c}70.22 \pm \\
0.05\end{array}$ & $\begin{array}{c}79.18 \pm \\
0.07\end{array}$ & $\begin{array}{c}84.25 \pm \\
0.03\end{array}$ \\
\hline \multirow[t]{2}{*}{5} & $\begin{array}{c}\text { Sampel } \\
\text { A }\end{array}$ & $\begin{array}{l}\text { Sampel } \\
\text { D }\end{array}$ & $\begin{array}{c}\text { Sampel } \\
\text { G }\end{array}$ \\
\hline & 0.104 & 1.411 & 1.882 \\
\hline \multirow[t]{2}{*}{10} & $\begin{array}{c}\text { Sampel } \\
\text { B }\end{array}$ & $\begin{array}{c}\text { Sampel } \\
\text { E }\end{array}$ & $\begin{array}{c}\text { Sampel } \\
\mathrm{H}\end{array}$ \\
\hline & 0.744 & 1.608 & 2.084 \\
\hline \multirow[t]{2}{*}{15} & $\begin{array}{c}\text { Sampel } \\
\text { C }\end{array}$ & $\begin{array}{c}\text { Sampel } \\
\text { F }\end{array}$ & Sampel I \\
\hline & 1.124 & 1.745 & 2.245 \\
\hline
\end{tabular}

Table 2 shows that the temperature is fluctuating around desired temperature. This is because the measurement changes due to the temperature of the environment. Hence, the temperature is calculated on average with the standard deviation. Table 2 shows that the results obtained that the higher the temperature given to the sample, the higher the maximum absorbance or can be said also as the content of BPA. This is similar results on the hot food that is packaged by plastic material. The hotter food create more possibility of BPA migration [9].

C. Bisphenol A (BPA) content with contact time variations

Bisphenol A (BPA) analysis with various contact times using a UV-VIS Spectrophotometer showed results as shown in table 3 . 
Nugroho et al.

Table 3. Maximum absorbance in each sample

\begin{tabular}{cccc}
\hline $\begin{array}{c}\text { Temperatures } \\
\left({ }^{\circ} \mathrm{C}\right)\end{array}$ & \multicolumn{3}{c}{ Contact Times (Minute) } \\
\cline { 2 - 4 } & 5 & 10 & 15 \\
\hline $70.22 \pm 0.05$ & $\begin{array}{c}\text { Sampel } \\
\text { A }\end{array}$ & $\begin{array}{c}\text { Sampel } \\
\text { B }\end{array}$ & $\begin{array}{c}\text { Sampel } \\
\mathrm{C}\end{array}$ \\
& & & \\
\cline { 2 - 4 } & 0.104 & 0.744 & 1.124 \\
\hline $79.18 \pm 0.07$ & $\begin{array}{c}\text { Sampel } \\
\mathrm{D}\end{array}$ & $\begin{array}{c}\text { Sampel } \\
\mathrm{E}\end{array}$ & $\begin{array}{c}\text { Sampel } \\
\mathrm{F}\end{array}$ \\
& & & \\
\cline { 2 - 4 } & 1.411 & 1.608 & 1.745 \\
\hline $84.25 \pm 0.03$ & Sampel & Sampel & Sampel \\
& $\mathrm{G}$ & $\mathrm{H}$ & $\mathrm{I}$ \\
& & & 2.245 \\
& 1.882 & 2.084 & \\
\hline
\end{tabular}

Table 3 states that with increasing contact times the maximum absorbance also increases. This is consistent with other result of BPA concentration on hoot food. The BPA migration can increase when the contact time increases, the contact temperature increases, the more additives in the packaging material, the level of contact and the level of food aggressiveness [10].

To show the comparison between the effect of temperature and contact time to the absorbance, the $3 \mathrm{D}$ graphics is shown in figure 4 . The $\mathrm{X}$-axis is the temperatures, the $\mathrm{Y}$-axis is the contact times, and the $\mathrm{Z}$-axis is absorbance. The rate of BPA migration from plastic cups to drinks or liquids is dominated by the influence of temperature. While contact time also affects but relatively small influence.

The increase in maximum absorbance at temperature and contact time can be interpreted as an increase in the concentration of BPA. BPA concentrations that are soluble in water can be identified using the Lambert-Beer Law.
The Content Analysis of Bisphenol a (Bpa) on Water in Plastic Glass with...

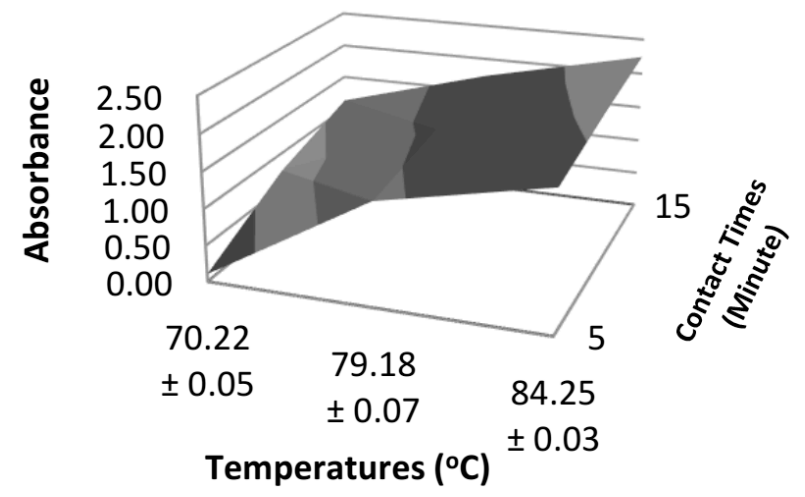

Figure 4. The 3D graph of absorbance dependence on temperature and contact time

Determination of BPA concentration requires a standard sample from the BPA to determine the value of $\varepsilon$ or constant molar absorption. Due to the difficulty of getting a standard sample from BPA, the alternative is to use the BPA absorption spectrum as shown in Figure 2. The line in figure 2 is tracked using the tracker software to determine the molar absorptivity $(\varepsilon)$ of the BPA as shown in Figure 5.

From the tracking process, the value of absorbance and concentration can be obtained. Those values are plotted in figure 5. The slope is the molar absorptivity $(\varepsilon)$ of the BPA.

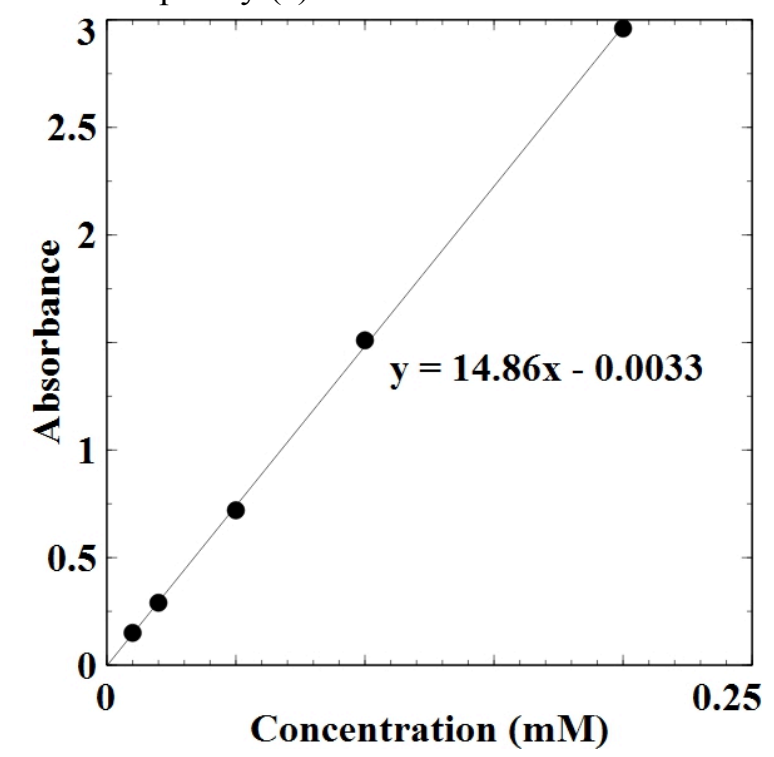

Figure 5. The relation between absorbance and concentration of BPA.

From figure 5 and the cuvette thickness of $1 \mathrm{~cm}$, the value of molar absorptivity $\varepsilon$ is $14.86 \mathrm{mM} . \mathrm{cm}^{-1}$. Hence, the concentration of each sample obtained from the variation of temperature and contact time is shown in table 4. 
Referring to the EFSA which has set an acceptable daily BPA intake (Tolerable Daily Intake, TDI) of $50 \mu \mathrm{g} / \mathrm{kg} /$ day or ppb / day so that the use of BPA remains declared safe to be consumed. Hence, based on the data that has been obtained from the highest concentration $(34.449 \mu \mathrm{g}$. $\mathrm{Kg}^{-1}$ ) in sample I, the sample is stated to be still in the safe category for once daily intake.

Table 4. Concentration of Bisphenol A (BPA)

\begin{tabular}{cccc}
\hline Sample & $\begin{array}{c}\text { Maximum } \\
\text { Absorbance }\end{array}$ & $\begin{array}{c}\text { Concentration } \\
\left(\mathrm{mM} . \mathrm{L}^{-1}\right)\end{array}$ & $\begin{array}{c}\text { Concentration } \\
\left(\mu \mathrm{g} . \mathrm{Kg}^{-1}\right)\end{array}$ \\
\hline $\mathrm{A}$ & 0.104 & 0.007 & 1.642 \\
\hline $\mathrm{B}$ & 0.744 & 0.050 & 11.46 \\
\hline $\mathrm{C}$ & 1.124 & 0.076 & 17.29 \\
\hline $\mathrm{D}$ & 1.411 & 0.095 & 21.70 \\
\hline $\mathrm{E}$ & 1.608 & 0.108 & 24.72 \\
\hline $\mathrm{F}$ & 1.745 & 0.118 & 26.82 \\
\hline $\mathrm{G}$ & 1.882 & 0.127 & 28.92 \\
\hline $\mathrm{H}$ & 2.084 & 0.140 & 32.02 \\
\hline $\mathrm{I}$ & 2.245 & 0.151 & 34.49 \\
\hline
\end{tabular}

\section{Conclusion}

1. In the study of the analysis of the content of Bisphenol A (BPA) with a temperature variation of $\pm 70^{\circ} \mathrm{C}$, temperature of $\pm 80^{\circ} \mathrm{C}$, and temperature of $\pm 90^{\circ} \mathrm{C}$ it is known that with the increasing temperature given to the sample, the higher the Bisphenol A content in the sample.

2. In the analysis of Bisphenol A (BPA) content with a variation of contact time of 5 minutes, 10 minutes, and 15 minutes it is known that with the increasing contact time given to the sample, the more Bisphenol A content contained in the sample is increased.

\section{References}

[1] Brotons, J. A., Olea-Serrano, M. F., Villalobos, M., Pedraza, V., Olea, N. Xenoestrogens Released from Lacquer Coatings in Food Cans, Environmental Health Perspectives, vol. 103, no. 6, 1995, pp 608-612

[2] Olea, N., Pulgar, R., Perez, P., Olea-Serrano, F., Rivas, A., Novillo-Fertrell, A., Pedraza, V., Soto, A. M., Sonnenschein, C. Estrogenicity of Resin-based Composites and Sealants used in Dentistry, Environmental Health Perspectives, vol. 104, no. 3, 1996, pp 298-305.

[3] Biles, J. E., McNeal, T. P., Begley, T. H., Hollifield, H. C. Determinations of Bisphenol-A in Reusable Polycarbonate Food-Contact Plastics and Migration to Food-Simulating Liquids, Journal of Agricultural and Food Chemistry, vol. 45, 1997, pp 3541-3544.

[4] Wardani, F. P., Toifur, M., Pramudya, Y. Perancangan Eksperimen Penentuan kadar Alumunium pada Minuman kemasan Kaleng Menggunakan Spektroskopi UV-VIS, Prosiding Seminar Pendidikan Fisika, Fisika, dan Aplikasinya, 2016, pp 179-186.

[5] Siregar, N. H., Pramudya, Y., Penentuan Kadar Limonene pada Minyak Kayu Putih Hasil Penyulingan Menggunakan Prinsip Spektroskopi UV-VIS, Prosiding Seminar Nasional Quantum, 2016, pp 353-358.

[6] Nugroho, B., Pramudya, Y. The Analysis Content of Bisphenol A (BPA) on Water in Glass Beverage Plastic with Time-Varying Contacts using UV-VIS Spectrophotometer, Proceedings International Seminar on Mathematics, Science, and Computer Science Education, Chemistry and Chemistry Education Section, 2015, pp. 498-502.

[7] Syarif, R. Teknologi Pengemasan Pangan Lanjut, STIKOM Surabaya, 2013.

[8] Lu, CH., Wang, Y., Li, Y., Yang, HH., Chen, X., Wang, XR. Bifunctional Super Paramagnetic Surface Molecularly Imprinted Polymer Core-shell Nanoparticles, Journal of Materials Chemistry, vol. 19, no. 8, 2009, pp 1077-1079.

[9] Winarno, F.G. Kimia Pangan dan Gizi, Gramedia Pustaka Utama, 1997.

[10] Nasruddin, M.N. Studi dan Simulasi Permodelan Laju Difusi Aditif Asam Stearad dan Asam Palmitat Dalam Zat Padat Polimer Polivinil Klorida, Dissertation, Universitas Sumatera Utara, Medan, 2010. 